\title{
Didactic Itineraries in the Cultural Heritage Education: Keys for Their Implementation
}

\author{
Ana Luisa Martínez-Carrillo*, Maria José Ortega-Chinchilla, Daniel Jesús Martín-Arroyo Sánchez, \\ Salvador Mateo Arias Romero
}

Department of Didactic of Social Sciences, University of Granada, Granada, 18071, Spain

Received June 30, 2021; Revised November 20, 2021; Accepted December 13, 2021

\section{Cite This Paper in the following Citation Styles}

(a): [1] Ana Luisa Martínez-Carrillo, Maria José Ortega-Chinchilla, Daniel Jesús Martín-Arroyo Sánchez, Salvador Mateo Arias Romero , "Didactic Itineraries in the Cultural Heritage Education: Keys for Their Implementation," Universal Journal of Educational Research, Vol. 10, No. 2, pp. 160-172, 2022. DOI: 10.13189/ujer.2022.100205.

(b): Ana Luisa Martínez-Carrillo, Maria José Ortega-Chinchilla, Daniel Jesús Martín-Arroyo Sánchez, Salvador Mateo Arias Romero (2022). Didactic Itineraries in the Cultural Heritage Education: Keys for Their Implementation. Universal Journal of Educational Research, 10(2), 160-172. DOI: 10.13189/ujer.2022.100205.

Copyright $\bigcirc 2022$ by authors, all rights reserved. Authors agree that this article remains permanently open access under the terms of the Creative Commons Attribution License 4.0 International License

\begin{abstract}
This article presents a proposal for the implementation of didactic itineraries in the Spanish curricula from the perspective of the cultural heritage. The teaching and learning of the cultural heritage can be approached through the use of an active and participative methodology such as didactic itineraries. It is essential to know the evolution of these in the Spanish curricula and to analyse the current legislation in educational matters in order to propose the programming of didactic itineraries from the current perspective. Based on these two main objectives, a qualitative analysis of the legislation has been carried out through a search for key words that denote the presence of educational pathways in educational programmes. On the other hand, a detailed description of how didactic pathways should be planned has been carried out. It has been exposed the different parts which compose them, identifying the weak points that teachers may know in order to facilitate the implementation of these resources. In addition, we have included a series of current digital repositories which contain textual, graphic and multimedia information on heritage assets that provide a valuable source of information that can be used in the classroom before and after the didactic itineraries. Through this review, this detailed description and the analysis of the current legislation, the main aim is to ensure that educational itineraries move from having little or no implementation in teachers' programmes to being included in them, given the high didactic potential that can be derived from them.
\end{abstract}

Keywords Didactic Itineraries, Cultural Heritage, Education, Spanish Curricula

\section{Introduction}

Heritage Education has been consolidated in Spain due to the creation of the Cultural Observatory of Cultural Heritage Education (since 2010) [1] and the National Education and Heritage Plan (PNEyP) created (since 2015) [2]. The National Plans arose from the need of heritage management instruments capable of developing criteria for action, methodologies and programming of activities aimed at heritage conservation, restoration, research, documentation, training and dissemination. The PNEyP focused on the importance of bringing together educational institutions and public administrations responsible for safeguarding the cultural heritage. The PNEyP insists on the need to strength links between people and cultural heritage based on the firm conviction that only the cultural heritage which is known, valued and respected can be conserved and protected. In this sense, education plays a fundamental role in the formal, non-formal and informal spheres.

In the sphere of formal education, the PNEyP has achieved a significant quantitatively and qualitatively increase of heritage content in the curricula. In this way, heritage has acquired greater prominence in Spanish schools, high schools and universities. This fact has 
brought with it the need to design methodological strategies and to think teaching resources that would allow the main objective of heritage education: to educate in, from and through the cultural heritage.

Among the methodological strategies, the most effective in the teaching and learning of cultural heritage are: Project Based Learning (PBL), Service Learning and, of course, didactic itineraries.

These lasts are the theoretical object of this work. We have tried to expose the keys for their implementation in a context of cultural heritage education. We begin with a brief overview of how itineraries have been approached as didactic tools from different areas of knowledge from the end of the 19th century until the present. This is followed by an analysis of their presence in the curricula of Childhood Education, Primary Education, High School and Baccalaureate. Finally, the last two sections define the phases which form a didactic itinerary in order to serve as a guide or model when designing these resources from a cultural heritage perspective. Also, a series of materials and resources, mainly digital, are included. This can serve as support in the development of proposals of cultural heritage itineraries.

\section{Didactic Itineraries in the Spanish Scientific Panorama}

The pedagogical itinerary as didactic resource in the teaching-learning processes of certain areas of knowledge has a long history in Spain. The pedagogical renewal movement carried out by men and women linked to the Institución Libre de Enseñanza (ILE) (Free Institution of teaching) in this country from 1876 to 1939 , considered field trips and itineraries as an essential tool for students who had to observe, experiment and reflect on all the elements of the natural and cultural reality that surrounded him. "A day in the field is more useful than a day of class," declared Francisco Giner de los Ríos [3]; words that summarize one of the pedagogical principles of the ILE: the didactic potential of direct contact with nature, or if we want, with the environment.

This interest in outings and itineraries continued during the Second Spanish Republic (1931-1936). This is evidenced by the Order issued by the Head of First Education on August 8, 1934, which established the following: in the first day of the next academic year, all the national teachers, complying with a previously plan, carry out, at least once a month, instructive excursions that serve to introduce children to the artistic, historical and monumental values represented in the city by the Museums, Archives and Monuments. These visits will be directed either by teachers or by people of recognized cultural authority, and the knowledge that is acquired in these excursions will have a logical link with the rest of the subjects of the school program.

Later, the Civil War (1936-1939) and the arduous postwar period wiped out any hint of educational innovation. We will have to wait until the $70 \mathrm{~s}$, but especially the $80 \mathrm{~s}$, to find again educational proposals which value field trips and pedagogical itineraries.

The works that deal with didactic itineraries in the $80 \mathrm{~s}$ have a mainly geographical orientation, but also geological and botanical. We can highlight the work of Antonio Gómez Ortiz from 1985 due to the relevance that it has had among researchers in the didactics of Geography, becoming an obligatory appointment in their studies, but there were many more who in those years pointed out the didactic potential of pedagogical itineraries for the didactics of the aforementioned disciplines [4-8]. These were works of a theoretical nature or proposals for itineraries on specific areas of special geological, botanical or landscape relevance. Finally, it is worth noting that, at the end of this decade, we find in these proposals for itineraries through the landscapes the first signs of a concern - which will be growing - for environmental education.

In the $90 \mathrm{~s}$ we found the same trend, there are researchers on itineraries with a clear geographical and geological orientation [9], but with the potential for teaching and learning other social sciences: History and History of Art. In these cases, the value of historical city centres stood out especially [10].

Again, we must point out a couple of references in the use of the didactic itineraries for teaching Geography in this decade: Antonio Luis García Ruíz and Ángel Liceras Ruiz. The quote that we collect belongs to the first:

But if the study of the landscape constitutes the main object of the Geography, the approach to it, the study on the ground, and, ultimately, the direct observation, must constitute a teaching method by excellence and, consequently, the field work, the geographical excursion and the didactic itinerary, becomes the best resources to learn it [11].

Both have been carried out, from the University of Granada, since the 90s and in the case of Ángel Liceras, recently, an important work in the development of the didactic of the Geography, highlighting in some of their contributions the relevance of itineraries as a pedagogical practice that allows the development of concepts, procedures and attitudes. "The itineraries are situations that inscribe the observer in the landscape, so the observer is not a mere spectator, is part of that space", stated Liceras in one of his last works [12].

From the year 2000 theoretical studies and didactic proposals on pedagogical itineraries have two clear tendencies: geographical and landscape orientation linked to the environmental education - and cultural heritage education. Despite the prominence of these two lines, we cannot ignore the proposals for geological and botanical itineraries that are still present in some works [13].

As we have already indicated above, it must be highlighted that the practical proposals focused on the 
educational value of didactic itineraries in the field of Geography and the landscape. Whether in natural environments or in urban spaces, pedagogical itineraries continue to be considered as a fundamental tool for working on space from a geographical perspective, fundamentally from the direct analysis of cultural landscapes and in many cases from the perspective of the environmental education, as the numerous researchers published in the last two decades have shown. It must point out that itineraries help to develop in the students the competences related to "know to do", since they allow the implementation of meaningful, complex, practical and collaborative learning. In this sense, Ana María Hernández Carretero (University of Extremadura) [14] and Alfonso García de la Vega (Autonomous University of Madrid) [15] have made interesting proposals in recent years about the relations between cultural landscape and educational itinerary.

The second line that stands out in the scientific panorama on the theoretical and practical study of pedagogical itineraries in the last 20 years is, as we said in a previous paragraph, the cultural heritage one.

The prominence that Cultural Heritage Education has acquired since 2005 throughout Europe as an emerging discipline has caused that in the last 15 years different cultural institutions have opted to develop a very important work in terms of research, teaching and dissemination of the cultural heritage. The year 2005 corresponds to the establishment of the Framework Convention of the Council of Europe on the value of Cultural Heritage for society; Article 13 made it clear that: the Parties undertake to: a) facilitate the inclusion of the cultural heritage dimension at all levels of education, not necessarily as a subject of study in its own right, but as a fertile source for studies in other subjects; b) strengthen the link between cultural heritage education and vocational training; c) encourage interdisciplinary research on cultural heritage, heritage communities, the environment and their inter-relationship; d) encourage continuous professional training and the exchange of knowledge and skills, both within and outside the educational system.

Following these guidelines, Spain created the National Education and Heritage Plan in 2015, whose fundamental objective is: to strengthen ties between citizenship and cultural heritage, because only if citizens feel the cultural heritage as their own, they will develop the necessary awareness to contribute to its conservation and protection. In this process of raising awareness and valuing cultural heritage, education is essential.

In this point, urban didactic itineraries have acquired a special meaning, supported theoretically by all the contributions that have been made from the field of the didactic of Social Sciences. If some itineraries through the city centres were already planned in the $80 \mathrm{~s}$ and $90 \mathrm{~s}$, it will be from the year 2000 when they acquire a greater role as a resource for the teaching of historical-artistic, ethnographic or industrial heritage [16].

Therefore, the city, understood as a magnificent «box of heritage assets, both tangible and intangible which have acquired heritage value over time» [17] is shown, not only as a resource but also as a source of first order for teaching and learning cultural heritage issues. The city and more specifically the urban didactic itineraries facilitate the approach to the complex concept of cultural heritage through the analysis and study of heritage elements, both tangible and intangible, present in urban contexts and allow direct knowledge of the more significant heritage assets.

The fact that the city plays a special role in the design of educational itineraries about cultural heritage does not exclude the interest in rural cultural heritage, as can be seen in some of the proposals. We find again a research line which has not yet enjoyed a complete development.

Didactic is a living science which adapts to the concerns, interests and needs of current societies. When consulting the bibliography on didactic itineraries, we see how in recent years the reflections and proposals that place in the foreground issues that affect the whole of society, such as the gender perspective. Margarita M. Birriel and Carmen Rísquez reflected on the relationship between heritage, tourism and gender in the presentation of an interesting dossier published in the magazine of the Andalusian Institute of Historical Heritage in 2016 [18]. They advise about the deficiencies and dangers of the Androcentric Inherited Discourse that has prevailed in the development of research, dissemination and management of cultural heritage. As proof that it is possible to change the approach to construct an egalitarian heritage history in terms of gender, there are several works on didactic itineraries that are treated from this perspective.

Finally, it is necessary to refer to the way in which technologies have bursted into the field of the cultural heritage education. This new digital context has allowed the introduction of important novelties thanks to the easy access to the information. They offer to the students communities of different social, geographical and educational contexts as well as the establishment of networks which allow the spread of the teaching and learning process. Therefore, virtual itineraries, Augmented Reality, Google Earth or Instagram, are presented as new, motivating and useful resources of great potential for the design and implementation of didactic itineraries [19].

As a conclusion, we want to point out that despite the profusion of dilated over time works which show the educational value of didactic itineraries, the truth is that their implementation is increasingly punctual as a consequence of the organizational effort involved, the responsibility, the extensive programs that teachers must attend, or the lack of clear guidelines that allow teachers to put this tool in practice. This last handicap is the one that we intend to solve with this work, since among our 
main objectives is to establish the phases that should structure a didactic itinerary.

But before moving on to this section, we will stop to show the place that cultural heritage content and didactic itineraries occupy in the Spanish educational legislation.

\section{Didactic Itineraries and Their Relevance in the Curriculum}

According to the Spanish legislation [20, 21, 22 and 23], "curriculum is the regulation of the elements which determine teaching and learning processes" as is stated in LOMCE in page 12. In short, the curriculum is made up of objectives, competencies, content and teaching methodology, as well as standards, results and evaluation criteria. Spain is territorially organized in Autonomous Communities. They assume their own legal competences in education, following the guidelines given by the state. At a lower level in this organizational hierarchy, schools assume a fundamental role through their didactic programming.

They establish complementary activities, including didactic itineraries. These provisions of the centres are established based on practical issues, such as the accessibility of the teaching resources in the immediate environment.

Starting from these organizational bases, the programming of didactic itineraries is not a legal imperative in Spain. However, educational policies tend to promote them as methodological tools, fundamentally from the perspective of the cultural heritage education. In order to demonstrate this affirmation, a series of documents of the current legislation in Spain and in the Autonomous Community of Andalusia will be examined below. This analysis is carried out from the systematic search of a list of terms related to didactic itineraries. The quantitative representativeness of these terms will be considered, as well as all their qualitative importance and their significance within the pedagogical discourse of each legal document. It will be paid attention to the curricular bases of Pre-School Education (students from 0 to 6 years old), Compulsory Primary Education (6-12 years old) and Secondary Education (12-16 years old), as well as Baccalaureate (16-18 years old).

Table 1 collects the quantitative results of the terminological analysis of a series of laws (Royal Decrees and Orders) that develop the educational curriculum from Pre-School Education to High School [20-30]. Data are organized in two blocks; one of them for Spanish legislation [20-26] and the other for Andalusian legislation [27-30]. The name of each "Document" is developed in the "Bibliography" of this article. The search for terms has been carried out using abbreviations that allow locating different forms of the same lexical family (for example, starting with "muse.": "Museum", "museum", "musealization"...). Those results that do not refer to the subject of the article have been removed (for example, "curricular itinerary", instead of "didactic itinerary"). To highlight five numerical ranges in quantitative results, five-color scales (from white to dark gray) are applied. These scales are applied independently for the national (Spain) and regional (Andalusia) results, as well as for the data on "Heritage" and on the rest.

The quantitative results in relation to the lexical family of "Heritage" denote the highest incidence of cultural heritage content in Andalusian legislation. In the state one, the terminology is gathered in the field of Primary Education. For Secondary, it is mentioned in one of the twelve general objectives of this educational stage [21, 22]; there is no reference to the lexical family of "Heritage" in the most recent legislation [23]. On the contrary, Andalusian legislation gives importance to heritage content in Primary but adds a similar weight to Secondary and doubles it in Baccalaureate. The effect of the inclusion of "Cultural and Artistic Heritage of Andalusia" as a specific subject in the first year of the Baccalaureate must be considered in this duplication of contents.

Table 1. Terminology related to itineraries in the legal bases for the organization of the academic curriculum in Spain and Andalusia.

\begin{tabular}{|c|c|c|c|c|c|c|c|c|}
\hline Range & Stage & Document & Year & Heritage & Itinerary & Visit & Muse. & Excursion \\
\hline Spain & Pre-School & RD 1630 & 2006 & 0 & 0 & 0 & 0 & 0 \\
\hline Spain & Primary & RD 1513 & 2006 & 12 & 4 & 1 & 1 & 0 \\
\hline Spain & Primary & RD 126 & 2014 & 16 & 1 & 1 & 5 & 1 \\
\hline Spain & Sec./ Bac. & RD 1105 & 2014 & 1 & 0 & 0 & 0 & 0 \\
\hline Andalusia & Pre-School & Order 05/08 & 2008 & 7 & 0 & 1 & 1 & 2 \\
\hline Andalusia & Primary & Order 15/01 & 2021 & 73 & 9 & 7 & 20 & 0 \\
\hline Andalusia & Secondary & Order15/01 & 2021 & 71 & 0 & 11 & 7 & 0 \\
\hline Andalusia & Baccalaureate & Order 15/01 & 2021 & 196 & 0 & 26 & 6 & 1 \\
\hline
\end{tabular}


"Didactic itineraries" are not identified frequently with this specific terminology. However, its curricular implication appears in terms relating to visits, particularly those made to museums. As a synonym for "visit", the term "excursion" is rarely used. This shows the importance of detecting specific terminologies for a more complete measurement of the cultural heritage content. In Primary Education, "itineraries" are present in relation to Geometry and Mathematics, both in national and Andalusian legislation. The description of itineraries supposes the delineation and the elaboration of sketches on spatial and everyday contexts. The basic notions about movement, scale and surface can be conveniently worked through itineraries, expanding the frame of reference beyond the classroom and the school centre. In addition to the references to Mathematics, Andalusian legislation includes the realization of didactic itineraries among methodological resources for Natural Sciences. In the subjects of First and Second Foreign Languages, the preparation of itineraries, travel guides and tourist guides of the locality is suggested.

The "visit" appears in national legislation as an evaluation criterion in Art Education: "obtain information that will help to plan and to organize cultural visits [24]. Also, it is considered as an evaluable learning standard in Social Sciences "respects and assumes the behaviour which must be observed when visiting a museum or an old building" [25]. The Andalusian legislation for Pre-scholars indicates the significance of visits due to their episodic nature, being unusual cultural experiences in the daily lives of students. In Primary, it is aimed at the experimentation and treatment of problems of progressive complexity as a methodological strategy. The attitudinal aspect related to behaviour is reinforced as content and standards for the Social Sciences.

The diversification of the curriculum in Secondary and Baccalaureate explains the multiplication of references to "visits". These appear as resources within the methodological strategies of many subjects. Their optional character is made explicit repeatedly, which explains why they are not present among the contents, the evaluation criteria and the learning standards, as more specific and regular measures within the teaching practice. This leads to a lack of definition on the organization and evaluation of possible itineraries, giving freedom to the teacher, who will be able to carry them out according to their particular initiative, dispositions of the centre and the accessibility to suitable spaces. This lack of guarantees for students contrasts with the importance given to visits as an educational resource from the connection with the environment, motivation and entrepreneurship.

"Museum" appears in the national legislation among the contents, evaluation criteria and learning standards for Art Education, Social Sciences and Second Foreign Language. It is a space, among other possible ones, for carrying out activities and developing attitudes of respect and enjoyment towards culture. The treatment of the term "museum" is similar in Andalusian legislation for Primary. In Secondary, "museum" is mentioned in the methodological strategies section of subjects such as Physics and Chemistry, Geography and History as well as Latin. Among the specific subjects, it appears in the Plastic, Visual and Audiovisual Education strategies, as well as in Classical Culture. Only in this last subject it is included in relation to the objectives and evaluation criteria. In Baccalaureate, it is found more frequently among the objectives and contents of subjects such as Geology and History of the Contemporary World, as well as the specific subjects of Artistic Drawing and History of Music and Dance.

In the Andalusian legislation, opposed trends can be observed in the use of the terms "visit" and "museum". This is because in Secondary and Baccalaureate other spaces of interest are introduced for outings. It goes from a more traditional approach, with visits to spaces for Heritage Education in the historical-archaeological legacy, towards another that considers training in research, development and innovation. In the first case, next to the museum, a visit to archaeological sites is mentioned. In the second case, there are science museums, universities, laboratories and research institutes, natural spaces and mines. These visits are focused on contact with professionals and professional entrepreneurship. This perspective allows the creation of itineraries which integrate the treatment of natural and cultural heritage, as well as complementary visions of the historical, artistic, technological and industrial legacies.

\section{Phases of a Didactic Itinerary}

Didactic itineraries are a resource for the teaching of Social Sciences. With them, a correct integration of the students is achieved in carrying out various tasks in a practical and active way; as well as direct contact with the surroundings, the environment and, therefore, with the reality $[31,32]$. We start from an experimental contrast of theoretical events and facts. With this the students achieve a feeling of leading role in their teaching, going from being a passive element to becoming an active element. Before starting an itinerary, we have to take into account a series of questions: the teacher must adapt the objectives that are proposed to the level of teaching of their students and the subject, and it is advisable to carry it out as close as possible to the school. A correct result will depend largely on the teacher's knowledge, his explanations in the classroom, as well as the level of the students. In the same way, proposed activities will be focused on obtaining the expected answers for a subsequent sharing, with rigorous results.

When scheduling the activity, we must bear in mind the school calendar and therefore the conditions that it may 
pose to us. During the tour, students should not exceed more than three hours of work; otherwise we could cause boredom, tiredness and even finish it quickly and badly.

In the first moment, the number of students does not have to be a determining factor, although a large group is not recommended. If we start with a number greater than thirty, it is advisable in order to avoid crowds to start the itinerary at different points. This could be solved by dividing the students into small groups, accompanied by an adult or volunteers from the school.

The itinerary can be divided into three phases:

A. We will start from the base of the previous knowledge that the students may have, these being increased by the teacher. It is advisable to carry out a questionnaire in which the following items are collected: problems and situations that attract the attention of the students; suggestions and questions arising from observations "in situ" previously carried out by students; influence the most striking and motivating aspects.

B. Regarding the choice of the place to carry out the activity, it is advisable to take into account a series of aspects: proximity to the school and to the student's environment; projected objectives; possibility of treating different natural, social, cultural and environmental aspects in an integrated way; the different places for the educational itinerary can be divided into natural environment or urban environment: natural environment can be from a mountain range, a path, a beach, a protected natural space, etc. In the urban environment we can choose from a street, a park, a museum, a monument and even the schoolyard.

C. Preparation of the questionnaire: to carry out a correctly adapted questionnaire it is necessary to follow three essential phases: the first will be a "brainstorming", the second the selection of the material and the third phase, the preparation and writing of the questions and activities to be carried out.

For making a questionnaire as effective as possible it should be composed of the following sections: cover, presentation or introduction, objectives, materials, general situation map, detailed map of the specific area, development of questions and activities, sources of information and bibliographic documentation, conclusions and a final survey.

- The cover should include the name or title of the itinerary, as well as an image or drawing. To increase the motivation of the students, it can be organized a contest for choosing the design of the cover.

- The presentation consists of a prologue to the activity, with which it is intended to introduce the students to the itinerary and make some reflections in relation to the subject.
Objectives are intended for students; therefore they must be formulated in an accessible language. Its main task should be that students know the aims of the activity; as well as that they have elements of reference when drawing up the conclusions and evaluating the results. A distinction must be made between general and specific objectives.

- Regarding the material we start from the basis that a list of instruments is always necessary to work, and depending on the specific activity, we may need from a tape measure, pen, colored pencils, camera, camera video, even a compass, etc.

- General situation map; depending on whether it is an itinerary in the nature or in an urban area, we will need a topographic map of the area or a map of the urban street map. It is advisable to include the cardinal points for orientation purposes.

- Detailed plan of the specific area. The chosen area or route to carry out the educational itinerary is detailed by a sketch easy-to-understand. It should reflect both, the exact location of the stops and the specific path to be followed.

- Development of questions and activities. Both of them should be distributed over a series of stops and occasionally on the route between them. The stops must be indicated on the map in detail and will be reinforced throughout the questionnaire. Similarly, an alternation of questions (written work) with activities (manipulative work) must be applied. Issues and activities must be varied; it is also advisable to introduce some multiple choice questions.

- Information sources and bibliographic documentation. Certain questions or activities may require a specific consultation of bibliography, documents or internet sources. After completing the itinerary, it should be outlined in the workbook.

- Conclusions and final survey. It should be included questions about the difficulties encountered during the filling of the questionnaire and about the learned lessons. Also the students may have the opportunity to make proposals for solving observed problems. A general opinion about the activity should also be included, as well as pointing out the positive and negative aspects of this type of work.

In short, it can be said that didactic itineraries are part of the practical activities that are followed in a constructivist methodology [33].

We can find some problems regarding by outings: few supporting documents, insufficient teacher training, lack of funding, shortage of time due to the classroom programming and scarcity interdisciplinary.

Among the different methods that we find in field work, we can highlight: itinerant excursions, naturalist routes, cultural routes and didactic itineraries [34, 35]. 
During the itinerant excursion, the teacher accompanies his students on a visit where it is shown different aspects of it. Therefore, we start from a teacher whose role is active, compared to a student whose role is passive, with this type of itinerary; the only thing that is achieved is the replacement of the textbook by the teacher and the classroom by another space. This may have a series of implicit problems such as the teacher's greater or lesser capacity for knowledge and, on the other hand, the greater or lesser performance of the student, due to the dispersion of attention.

The natural routes, as well as the cultural ones, are usually elaborated by councils, autonomous communities, etc. Their purposes are very diverse: touristic, scientific, sports or cultural. They consist of marked itineraries though detailed guides with information on the natural or cultural resources present along the itinerary. One of the main problems that we find with this type of route is that they are not designed for educational purposes [36]. Also, the guides are designed for adults and therefore, they are inadequate from a didactic point of view, with objectives and contents of different levels of education.

Didactic itineraries are the most advisable ones in any education system due to the following reasons:

In a didactic itinerary there are multiple activities carried out outside the classroom (countryside, city, museums, etc.), in which the student is an active part and protagonist. The activity takes place in a place or along a route chosen by the teacher, with specific stops, not necessarily coinciding with those indicated in the official itineraries [37].

Students must be provided with an edited notebook containing a series of questions and activities that they must carry out "in situ". In this way students will be active and busy continuously along the itinerary, having the possibility of working alone or in a team.

\section{Resources and Materials}

Digital resources and the media are having a great impact on new ways of classifying teaching competencies. Although teachers and students live immersed in media experiences, the transfer to the teaching and learning process has not been fully carried out [38]. There are still reservations about its use closely related to teacher training. In addition, this training is the variable that most influences the level of digital competence of teachers according to González, Gozálvez and Ramírez [39].

In this sense, the area of knowledge related to the teaching and learning of cultural heritage has not remained unconnected to this dynamic, so it is essential to train future teachers in digital skills to expand the knowledge of students with visual technologies.

Within the programming of a didactic itinerary it is essential to be able to have didactic resources that can be useful to obtain information and to visualize it in activities before or after the didactic itinerary in order to acquire and establish the knowledge that our students must acquire. Digital resources can be found in the following on line repositories:

\section{- Online database Digital Network of Museum Collections [40].}

The Digital Network of Museum Collections in Spain brings together museums of different specialties, of various thematic and geographical areas, and of different ownership, public and private, with the aim of making digital content about their collections accessible online and creating a space for dissemination of knowledge about them.

\section{- DOMUS repository [41].}

Domus is an Integrated System of Documentation and Museum Management developed by the Ministry of Culture and implemented in the Museums of Andalusia by the Ministry of Culture and the Ministry of Culture of the Junta de Andalucía to facilitate citizen access to Andalusian heritage. It is a computer application for the catalogue and management of cultural assets guarded by museums.

\section{- General Catalog of Andalusian Historical Heritage [42].}

The General Catalog of Andalusian Historical Heritage includes Assets of Cultural Interest, general cataloging assets and those included in the General Inventory of Movable Assets of the Spanish Historical Heritage.

In addition, the catalogue includes the inscriptions as Assets of Cultural Interest under Law 16/1985 of June 25 on the Spanish Historical Heritage. This catalogue is available in open data format.

On the other hand, it should also be noted that there are some online repositories that allow viewing 3D models of objects related to cultural heritage. The most relevant are the following:

- Europeana Repository [43]. It access is intuitive, already on the home page you can search in different languages through free text. The multimedia material has been divided into 3D models, text, image and videos, so it is possible to filter 3D models (Figure 1). One of the results of "Roman sculpture" leads us to a 3D model of the sculpture of a lion preserved in the Monographic Museum of Cástulo (Linares, Jaén). The 3D model has an associated description and the 3D model is downloaded in the form of .pdf, which is a fairly common format that has the particularity of supporting interactive models. The $3 \mathrm{D}$ viewer is not integrated into the web page, so you have to download the model and open it with the Adobe 
Acrobat software. On the same search page, there are two images associated with the model and a location of the site where it was located through Google maps, so it is contextualized both temporally and spatially.

The metadata is arranged following a predetermined scheme, so the search for content and the information associated with it is accessible and intuitive. In addition, other associated items are shown in the search, so it is easy to find 3D models related by chronology or collection. 3D models are of quality, since both the shape and the texture are displayed correctly.

- Sketchfab [44]. This page is an online repository where 3D content can be viewed and shared. It is not a site specialized in 3D models of heritage assets, but rather a site where models of various types are shared. On its home page it has a search engine where you can access more specific information. Thus, introducing the term "museum" an organization (add \& 4d) has appeared that has digitized movable and immovable property of Spanish settlements. Among these goods is the "dame of Galera" (Granada) (Figure 2), currently preserved in the National Archaeological Museum (Madrid). The models uploaded by this organization only have an identifier and the name of the heritage asset, there is no other associated information, so knowledge of them is quite partial. Although Sketchfab allows adding annotations in the 3D model, this is not required, so it can be inferred that there is no metadata schema when adding additional information from 3D models.
Regarding the visualization of the models, the one consulted has been of high quality since the models have a sufficient resolution to be able to contemplate the details of the forms.

- Google Arts and Culture [45]. It is a website of the Cultural Institute of Google that presents a compilation of high resolution images of works of art exhibited in various museums around the world, as well as a virtual tour of the galleries in which they are located. All works are shown in high resolution. Mainly the repository is made up of pictorial works, although you can also find 3D panoramas of interiors and exteriors of buildings. This is the case of the Toya chamber, whose replica can be visited in the Provincial Museum of Jaén and which can also be visited virtually through this platform. In addition to visual resources such as high-resolution photographs and 360-degree views of buildings, a short description of each heritage asset is included that makes it easier to understand. The search can be done through free text or through search through Google maps, thus adding the spatial component, so the search is better defined and complete, also offering the user nearby sites available to be able to be visited in person or virtually.

3D models that are shown in these repositories constitute top-level didactic resources since they can be easily accessible from ICT resources such as smartphones, tablets or computers, in addition to facilitating a three-dimensional manipulation similar to the tangible model. 
Resultados: 84

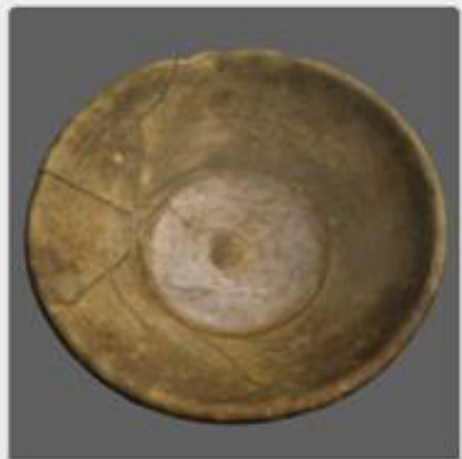

Recipiente cerámico LN389 de la tumba $n^{\circ} 277$ de la necrópolis de La Noria (Fuente de Piedra...

Instituto de Arqueología ibéricaUniversidad de Jaén

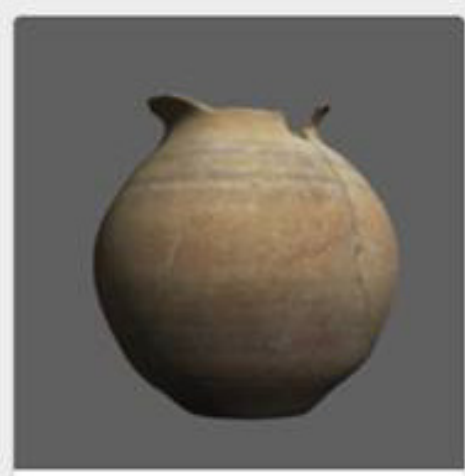

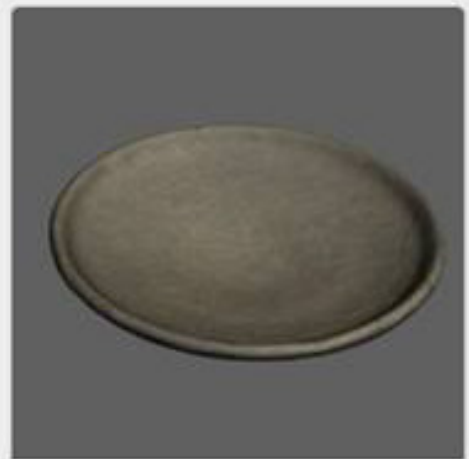

Recipiente cerámico LN133 de la tumba $n^{\circ} 233$ de la necrópolis de La Noria

(Fuente de Piedr...

Instituto de Arqueología Ibérica. Universidad de jaén
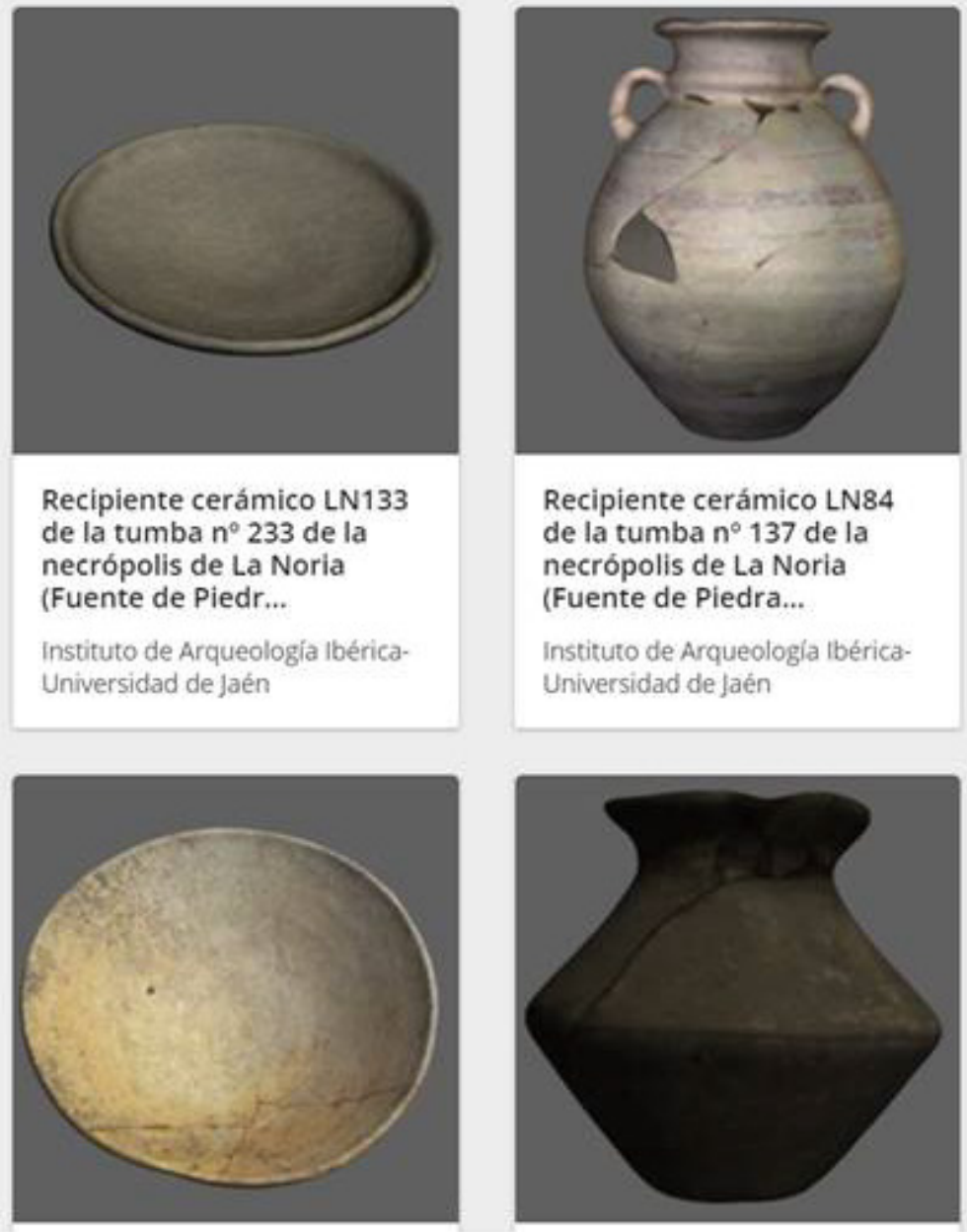

Recipiente cerámico LN84 de la tumba $n^{\circ} 137$ de la necrópolis de La Noria (Fuente de Piedra...

Instituto de Arqueologia lbéricaUniversidad de jaén

Universidad de ján

Figure 1. Screen shot of 3D pottery models from Europeana website.

:三 乼

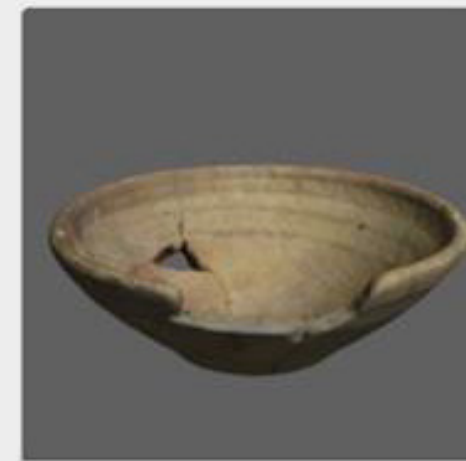

Recipiente cerámico LN129 de la tumba ${ }^{\circ} 231$ de la necrópolis de La Noria (Fuente de Piedr..

Instituto de Arqueologia IbéricaUniversidad de jaén

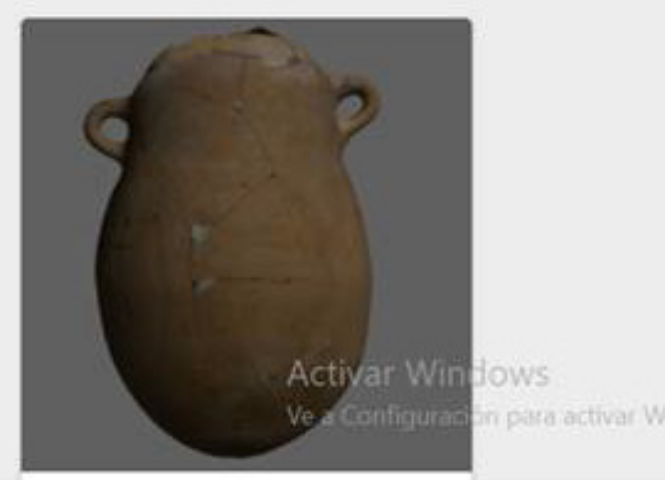




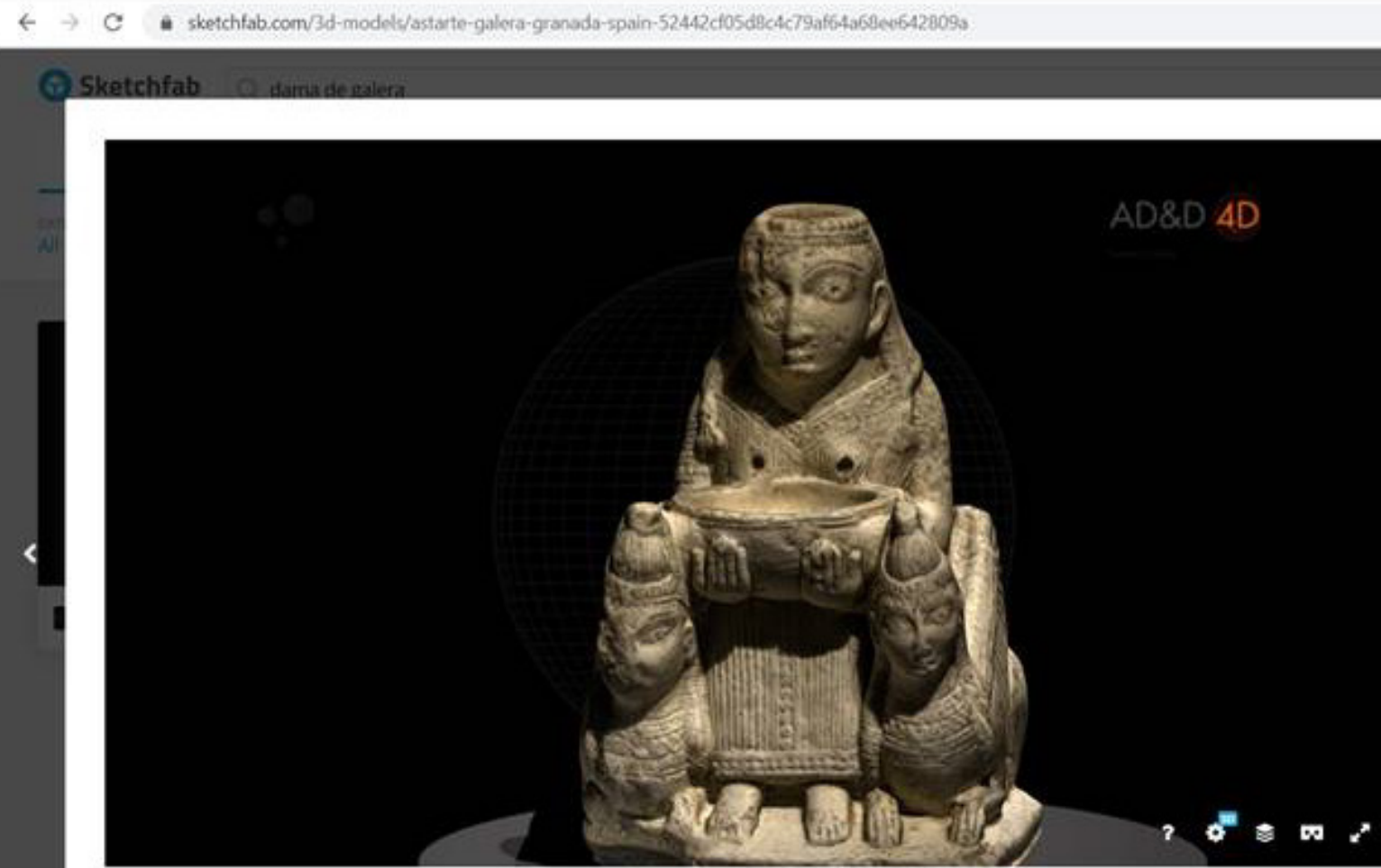

Astarté / Galera / Granada / Spain

AD\&D 4D W0

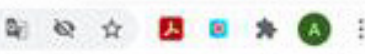
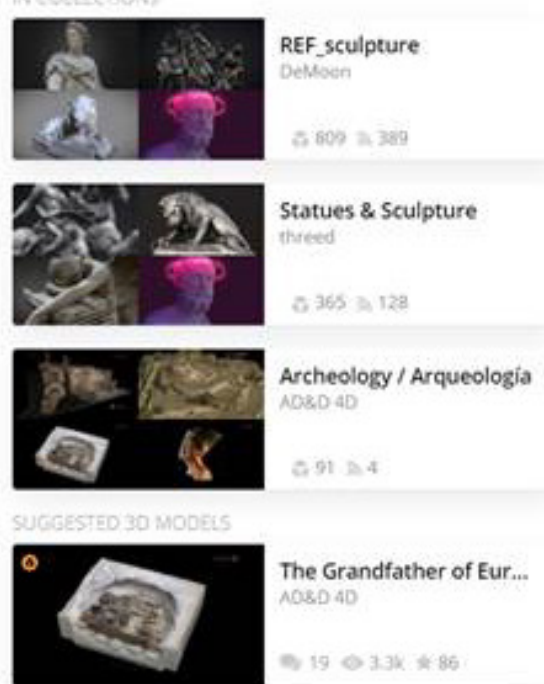

The Grandfather of Eur

$19 \circ 33 x * 8$

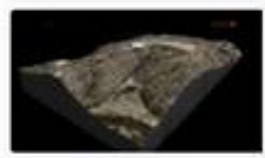

Necrópolis de Tútugi $\mid G$.

DSD 4D

$03032+14$ 230 Act Castellón Aito 1 Galera...

Figure 2. Screen shot of the 3D model of the dame from Galera in the Sketchfab website. 
3D models when are perceived visually can stimulate visual exteroceptive sensations that come from the outside. They also provide greater voluntary attention from the students due to external factors such as novelty and the intensity of stimuli in the perceptual field.

\section{Conclusions}

The didactic itinerary is a valuable resource for heritage education. Teachers are generally aware of it, but further definition and study of this resource is needed for it to be utilised to its full potential.

First of all, it must be distinguished from itinerant routes and excursions. Nature and cultural routes have no pedagogical purpose. The difference between itinerant excursions and didactic itineraries is the active participation of the students carried out in the first one. It is therefore a practical resource, based on constructivist methodology and seeks meaningful learning.

Secondly, this paper highlights the evolution and future prospects for the use of educational pathways. To do so, it focuses on the educational conditions of the Spanish system, showing the historiographical development, the current legislation and some new resources in relation to the itineraries.

The use of school outings has been present in the modernisation of the education since the 1930's. However, itineraries have appeared in research articles mainly since the 1980 's. At that time, they were dealt with from an environmental approach, centred on the landscape. At that time, they were dealt with from an environmental approach, centred on the landscape. In the 1990s, the art-historical perspective was incorporated. Publications from both approaches have multiplied in the 21 st century. New trends include the heritage treatment of urban environments, the application of information and communication technologies, as well as gender studies. In this context, heritage education is developing as an emerging discipline, encouraged by international institutions, as can be seen in article 13 of the Council of Europe Framework Convention on the Value of Cultural Heritage for Society.

The analysis of Spanish education legislation shows how international initiatives affect the national level. In the Spanish case, this influence is conditioned by the delegation of educational competences to regional governments. The implementation of heritage education is unequal across Spain. The region of Andalusia stands out positively in this respect. Its legislation stresses the importance of heritage education and shows its cross-cutting nature with respect to the different subjects and educational stages. At the same time, this legislation points out the great potential of didactic itineraries as an educational resource. The terminological analysis shows a certain conceptual evolution of the itinerary from Primary to Secondary and Baccalaureate. There is a shift from a classical cultural itinerary towards a broader notion, which includes a practical orientation towards economics and professional entrepreneurship. This contrasts with the lack of analysing studies about the use of itineraries in the experimental sciences.

Nowadays, the possibilities for implementing itineraries have been considerably multiplied by the technological revolution of the information society. This paper shows some examples, focusing on the repositories of Spanish and European museum collections. These make it possible to plan itineraries in museums, where the prior selection of stops becomes more necessary, avoiding the overload of information during visits. Also, beyond the itinerary as an outing outside the school, these tools make it possible to plan and provide more relevant content for the activities before and after the visit. The itinerary is thus reinforced in its potential effectiveness. It is conceived as a resource that includes the prior preparation of theoretical contents and is aimed at the development of the research, as a way of extending and consolidating the knowledge acquired in the field. The aim here is not to provide an exhaustive catalogue of the new tools available for the implementation of itineraries, but rather to give a series of examples that reinforce the idea of the itinerary as a resource integrated into a constructivist educational strategy.

In short, the didactic itinerary is a classic tool that can be used in a deficient way if its true potential is not reflected upon. The current educational context makes it possible to rethink the application of this resource. This is evident in the case of the new technologies available. On the other hand, from the political initiative in cultural matters, the emergence of heritage education implies the training of new citizens in close connection with their environment. Direct knowledge, through work in the field, becomes an essential way to achieve greater awareness and active participation in the conservation and improvement of cultural heritage. This study provides a conceptual and practical basis for explaining the role of educational trails in Spain, as well as their potential in the context of new international policies for the promotion of education and culture. With all this, it is hoped to awaken a renewed interest in the educational community and to achieve a greater methodological development of the didactic itinerary as a fundamental resource at all stages of education.

\section{REFERENCES}

[1] O. Fontal Merillas, "El Observatorio de Educación Patrimonial en España", Culture and Educación, Cultura y Educación", Vol. 28, № 1, 254-266, 2016. 
[2] Ministerio de Educación, Ciencia y Deporte. Plan Nacional de Educación y Patrimonio, 2015. Online Available https://sede.educacion.gob.es/publiventa/descarga.action?f _codigo_agc $=15106 \mathrm{C}$

[3] Gaceta de Madrid, no 221, p. 1389, 9 de agosto de 1934, Online Available: https://www.boe.es/datos/pdfs/BOE//19 34/221/A01389-01389.pdf

[4] A. Gómez Ortiz, "Los itinerarios pedagógicos como recurso didáctico en la enseñanza de la Geografía en la E.G.B", Didáctica geográfica, $\mathrm{N}^{\mathrm{o}} 14,109-116,1986$. https://dialnet.unirioja.es/metricas/documentos/ARTREV/ 3661743

[5] A. Obrador Tuduri, J. Bach i Plaza, "El itinerario urbano en el aprendizaje de la geología", Enseñanza de las ciencias: revista de investigación y experiencias didácticas, Vol. $5, \mathrm{n}^{\circ}$ Extra 1, 85-86, 1987.

[6] L. Rodríguez Armas, E. Beltrán-Tejera, "Itinerarios didácticos de botánica", Actas I y II Congresos Asociación Canaria para la Enseñanza de las Ciencias Viera y Clavijo, 146-155, 1988.

[7] B. López Limia, "El carst de la Sierra de Segura: propuesta de un itinerario didáctico", Espacio, Tiempo y Forma, serie VI, Geografía, Tomo 2, 315-328, 1989.

[8] P. Contreras Linares, M. Dolores López Raya . "Itinerarios didácticos de Ciencias Naturales", Revista Cultural y Científica, №5, pp. 13-40, 1995.

[9] A. M. Zárate Martín, "El itinerario urbano como estrategia de aprendizaje de la geografía", Didáctica Geográfica, № 1 , 21-34, 1996.

[10] E. M. Tonda Monllor, "Itinerario didáctico urbano. El valor educativo de los cascos históricos de las ciudades. El caso de Alicante", in Jesús Rafael de Vera Ferre, Emilia María Tonda Monllor y María Jesús Marrón Gaite: Educación y Geografía, 113-134, 1998.

[11] A. Liceras Ruiz, "Los itinerarios didácticos y el trabajo de campo en la enseñanza de la geografía", Revista de educación de la Universidad de Granada, №6, 141-166, 1992.

[12] A. Liceras Ruiz, "Los itinerarios didácticos en la enseñanza de la geografía, Reflexiones y propuestas acerca de su eficacia en educación", UNES: Universidad, escuela y sociedad, $\mathrm{N}^{\mathrm{0}} 5,66-81,2018$.

[13] J. Garrido Clavero, M. A. Sánchez del Árbol, G. J. Fernández, "Didáctica de las salidas de campo de geografía en las distintas etapas educativas: Primaria, Secundaria, Grado, Postgrado, Formación Abierta y Profesional", ReiDoCrea. Revista electrónica de investigación y docencia creativa, vol. 9, 155-172, 2020.

[14] A. M. Hernández Carretero, R. Gillén Peñafiel, J. L. Gurría Gascón, "Los itinerarios pedagógicos y las salidas escolares: experiencias sensitivas y aprendizajes significativos", in Ana María Hernández Carretero (coord.), Estrategias y recursos didácticos para la enseñanza de las Ciencias Sociales, Ed. Pirámide, Madrid, 55-72, 2019.

[15] A. García de la Vega, "La didáctica del paisaje a través de los itinerarios y la cartografía", Didáctica geográfica, $n^{\circ} 20$, 15-24, 2019.
[16] S. M. Arias Romero, J. Contreras García, M. Czestochowa Molina Serrano, J. Tenedor Tenedor, "El patrimonio granadino como elemento: un itinerario inclusivo por el Barrio de la Manigua", Foro educacional, $N^{\circ} 33,11-29$, 2019.

[17] M. E. Cambil Hernández, "La ciudad como recurso para la enseñanza aprendizaje del patrimonio cultural", Opción, Vol. 31, N³, 2015.

[18] M. M. Birriel Salcedo, C. Rísquez Cuenca, "Patrimonio, turismo y género", Estrategias para integrar la perspectiva de género en el patrimonio, $\mathrm{PH}, \mathrm{N}^{\mathrm{o}} 89,155-156$.

[19] J. F. Álvarez Herrero, “Aprendizaje móvil con itinerarios didácticos en alumnado de secundaria con geolocalización, realidad aumentada e Instagram”, in Eloy López Meneses, David Cobos Sanchiz, Laura Molina García, Alicia Jaén Martínez, Antonio Hilario Martín Padilla (coords.): Claves para la innovación pedagógica ante los nuevos retos: respuestas en la vanguardia de la práctica educativa, 1140-1148, 2020.

[20] LOMCE: Organic Law 8/2013, of December 9, for the improvement of educational quality. Head of state. Official State Gazette, 295, of December 10, 2013 (Reference: BOE-A-2013-12886). Madrid Spain. https://www.boe.es/b uscar/doc.php?id=BOE-A-2013-12886

[21] LOE: Organic Law 2/2006, of May 3, on Education. Head of state. Official State Gazette, 106, of May 04, 2006 (Reference: BOE-A-2006-7899). Madrid Spain. https://www.boe.es/buscar/doc.php?id=BOE-A-2006-7899

[22] RD 1105: Royal Decree 1105/2014, of December 26, which establishes the basic curriculum for Compulsory Secondary Education and Baccalaureate. Official State Gazette, 3, of January 3, 2015 (Reference: BOE-A-2015-37). Ministry of Education, Culture and Sports. Madrid Spain. https://www.boe.es/boe/dias/2015/01/03/pdfs/BOE-A-201 5-37.pdf

[23] LOMLOE: Organic Law 3/2020, of December 29, which modifies Organic Law 2/2006, of May 3, on Education. Head of state. Official State Gazette, 340, of December 30, 2020 (Reference: BOE-A-2020-17264). Madrid Spain. https://www.boe.es/buscar/doc.php?id=BOE-A-2013-1288 6

[24] RD 1513: Royal Decree 1513/2006, of December 7, which establishes the minimum teachings of primary education. Official State Gazette, 293, December 2006 (Reference: BOE-A-2006-21409). Ministry of Education and Science. Madrid Spain.https://www.boe.es/boe/dias/2006/12/08/pdf s/A43053-43102.pdf

[25] RD 126: Royal Decree 126/2014, of February 28, which establishes the basic curriculum for Primary Education. Official State Gazette, 52, of March 1, 2014 (Reference: BOE-A-2014-2222). Ministry of Education, Culture and Sports. Madrid Spain. https://www.boe.es/buscar/act.php?i $\mathrm{d}=$ BOE-A-2014-2222\&p=20140301\&tn=2

[26] RD 1630: Royal Decree 1630/2006, of December 29, which establishes the minimum teachings of the second cycle of Early Childhood Education. Official State Gazette, 4, of January 4, 2007 (Reference: BOE-A-2007-185). Ministry of Education and Science. Madrid, Spain. https://www.boe.es/diario_boe/txt.php?id=BOE-A- 


\section{7-185}

[27] Order 08/05: Order of August 5, 2008, which develops the curriculum corresponding to the Baccalaureate in Andalusia. Official Gazette of the Junta de Andalucía, 169, August 26, 2008, 17-53. Junta de Andalucía. Sevilla Spain. https://www.juntadeandalucia.es/boja/2008/169/3

[28] Order 15/01: Order of January 15, 2021, which develops the curriculum corresponding to the stage of Primary Education in the Autonomous Community of Andalusia, regulates certain aspects of attention to diversity, the organization of the evaluation of the student's learning process and determines the transition process between different educational stages. Official Gazette of the Junta de Andalucía, Extraordinary no. 7, of January 18, 2021, 2-223. Ministry of Education and Sports, Junta de Andalucía. Sevilla, Spain. https://www.juntadeandalucia.es/boja/2021 $/ 507 / 1$

[29] Order 15/01: Order of January 15, 2021, which develops the curriculum corresponding to the Compulsory Secondary Education stage in the Autonomous Community of Andalusia, regulates certain aspects of attention to diversity and determines the evaluation of the student's learning process and the transition process between different educational stages. Official Gazette of the Junta de Andalucía, Extraordinary no. 7, of January 18, 2021, 656-1024. Ministry of Education and Sports, Junta de Andalucía. Sevilla, Spain. https://www.juntadeandalucia.es /boja/2021/507/3

[30] Order 15/01: Order of January 15, 2021, which develops the curriculum corresponding to the Baccalaureate stage in the Autonomous Community of Andalusia, regulates certain aspects of attention to diversity and establishes the organization of the evaluation of the student's learning process. Official Gazette of the Junta de Andalucía, Extraordinary no. 7, of January 18, 2021, 224-655. Ministry of Education and Sports, Junta de Andalucía. Sevilla, Spain. https://www.juntadeandalucia.es/boja/2021/507/2

[31] J. A. Bailon Garzon, "Elaboración de Itinerarios Didácticos”, in Práctica docente, Revista digital $N^{\circ} 11,1-7$, 2008.

[32] P. Benejam, "Els objectius de les sortides", Perspectiva escolar $\mathrm{N}^{\circ} 204,2-9$.
[33] J. A. Frutos, "Sendas Ecológicas”, Madrid, CCSS, 1998.

[34] A. L. García Ruiz, "El proceso de desarrollo de los Itinerarios didácticos”, Didáctica de la geografía N², 1-10, 1997.

[35] F. J. Martínez López, "Itinerarios didácticos por Fuente Álamo", Espiral. Cuadernos del profesorado, Revista digital. Centro del profesorado de Cuevas-Olula, $\mathrm{N}^{\circ} 1$ 1-9, 2008 .

[36] F. Rojero, "La geolocalización de itinerarios ambientales y otras alternativas tecnológicas para la Educación ambiental", Revista de Didáctica ambiental, Nº 6, 2007.

[37] A. Sanchez Ogallar, "El trabajo de campo y las excursiones", Enseñar Geografía de la teoría a la práctica, Síntesis, Madrid 1995.

[38] A. Ramírez-García, N. González-Fernández, "Media competence of teachers and students of compulsory education in Spain", Competencia mediática del profesorado y del alumnado de educación obligatoria en España. Comunicar, 24(49), 49-58, 2016. https://doi.org/10.3916/C49-2016-05

[39] N. González-Fernández, V. Gozálvez-Pérez, A. Ramírez-García, A, "La competencia mediática en el profesorado no universitario", Diagnóstico y propuestas formativas. Revista de Educación $\mathrm{N}^{\circ}$ 367, 117-146, 1988. https://doi.org/10.4438/1988-592X-RE-2015-367-28 4

[40] Digital Network of Museum Collections. Online Available: http://ceres.mcu.es/pages/SimpleSearch?index= true

[41] DOMUS repository. Online Available: http://www.museo sdeandalucia.es/web/museosdeandalucia/fondos-museistic os

[42] General Catalogue of Andalusia Historical Heritage. Online Available: https://www.juntadeandalucia.es/organismos/cu lturaypatrimoniohistorico/areas/bienes-culturales/catalogopha/consulta.html

[43] Europeana. Online Available: https://www.europeana.eu/es

[44] Sketchfab. Online Available: https://sketchfab.com

[45] Instituto Cultural de Google. Online Available: https://artsandculture.google.com/?hl=es 